\title{
GABAL ABU HAMR PLUTON: AN EXAMPLE OF A-TYPE ANOROGENIC PERALKALINE GRANITES IN EGYPT
}

\author{
Abdel-Hamid, H. M. ${ }^{2}$, Abdel Kader, Z. M. ${ }^{1}$, El Manawi, A. W. ${ }^{1}$ and Abdel Warith, A. ${ }^{2}$ \\ 1 Geology Department, Faculty of Science, Cairo University, Giza, Egypt \\ 2 Nuclear Materials Authority, Cairo, Egypt. \\ e-mail: hichamel_hakim@hotmail.com
}

\begin{abstract}
Gabal Abu Hamr pluton is an elongated peralkaline granitic mass emplaced along the ENE-WSW Qena-Safaga shear zone as one of the anorogenic peralkaline granites represented in the Eastern Desert of Egypt. The rock is hypersolvus, composed of perthite, quartz and both alkali amphibole (arfvedsonite) and pyroxene (aegerine). It is enriched in $\mathrm{Si}, \mathrm{Na}, \mathrm{K}, \mathrm{Ba}, \mathrm{Y}, \mathrm{Ga}$ and LREE and depleted in $\mathrm{Al}, \mathrm{Mg}, \mathrm{Ca}, \mathrm{Mn}, \mathrm{Zr}$ and HREE. The rocks exhibit mineralogical and chemical traits typical of within-plate A-type granites, which, due to the ascending of hydrothermal solutions along the ENE-WSW strike-slip fault, dividing the pluton, suffered metasomatic processes causing the leaching of $\mathrm{Zr}, \mathrm{U}$ and HREE and their escape into the fluids and transported through the structure systems to be concentrated along the tectonic contact between the granite and the adjacent metavolcanics. This pluton may represent the northern extension of both $\mathrm{G}$. Abu Kharif and G. El Dob being emplaced along the same E-NE shear zone trend. The suggested age of emplacement of G. Abu Hamr pluton is from $550 \mathrm{Ma}$ to $450 \mathrm{Ma}$.
\end{abstract}

Keywords: Abu Hamr, anorogenic, peralkaline granite, A-type granite.

\section{INTRODUCTION}

G. Abu Hamr area is considered as part of the late-Proterozoic Pan-African belt. It is located at the northern part of the Arabian Nubian shield in the North Eastern Desert of Egypt.

The Arabian-Nubian Shield (ANS) forms the largest crustal segment of the Pan-African orogeny. It occurs within accreted terranes extending from Mozambique and Madagascar belts to Eastern Egypt, Sinai, Jordan, Western Arabia and Yemen that was formed in the late Proterozoic (Neoproterozoic) time as indicated by $\mathrm{U}-\mathrm{Pb}$ zircon ages, $\mathrm{Sr}-\mathrm{Nd}-\mathrm{Pb}$ and lead isotopic data (Stern, 2002; Stoeser and Frost, 2006 and Stern et al.,2010). The ANS juvenile crust was formed as result of a pre-collisional (island-arc) stage ( 820-700 Ma), a syn-collisional stage (670-630 Ma) and a post-collisional stage (630-580 Ma) as indicated by Farahat et al. (2007 and 2011). The collisional stage terminated at $\sim 615-600 \mathrm{Ma}$ and subsequence structural collapse occurred only within the 595-575 Ma time span and was followed by transperssional tectonism along major shear zones (Beyth et al., 1994).

Upon the termination of the Pan-African orogenic compressive tectonic activity $(\sim 550 \mathrm{Ma})$ an extended phase of anorogenic alkaline complexes was emplaced during nearly the entire Phanerozoic Era until the opening of the Red Sea $23 \mathrm{Ma}$ ago into the Pan-African crust of east Africa and Arabia (Abdel-Rahman, 1995 and 2006). Many of the alkaline complexes were emplaced along deep-seated, reactivated, PanAfrican fractures and shear zones, or at the intersection of such fracture systems (Fig.1).

Fig (1) shows examples of such complexes which are exposed in the Eastern Desert: G. Gharib (AbdelRahman and Martin, 1990a), Abu Khruq ring complex (Landoll et al., 1994), Wadi Dib ring complex (Frisch and Abdel-Rahman, 1999), G. El-Sibai (Abdel-Rahman and El-Kibbi, 2001), G. Abu Kharif and ElDob (Abdel-Rahman, 2006), in addition to G. Abu Hamr.

The peralkaline anorogenic nature of the granite of G. Abu Hamr pluton was determined by AbdelHamid (2009) for the first time in the area. Detailed genetic studies of its emplacement were not 
accomplished. The aim of this work is to characterize the petrological, geochemical, tectonic and metasomatic processes which accompanied the emplacement of this pluton.

Fig.1: Distribution and age of alkaline ring complexes (1-11) and other alkaline complexes (a-d) in the Egyptian belt of the Nubian shield: (1) Wadi Dib, 578 Ma; (2) Zargat Naam, 404 Ma; (3) Tarbtite (North), 351 Ma; (4) El Gezira, 229 Ma; (5) El Naga, 145 Ma; (6) El Mishbeh, 142 Ma; (7) Nigrub El Tahtani, 140 Ma; (8) Nigrub El Fogani, 139 Ma; (9) Mansouri, 132 Ma; (10) El Kahfa, $91 \mathrm{Ma}$; (11) Abu-Khruq, $89 \mathrm{Ma}$; (a) G. Gharib, $476 \mathrm{Ma}$; (b) G. El Zeit (not dated yet); (c) G. Abu-Kharif and El-Dob, $522 \mathrm{Ma}$ and G. Abu Hamr (not dated yet); and (d) G. El-Sibai, 490 Ma. The ages reported here are after El-Ramly (1962), Abdel-Rahman and Doig (1987), and Abdel-Rahman (2006). The shaded area defines the regional extent of the exposed Pan-African belt. Map and tectonic are after AbdelRahman (2006) modified after Garson and Krs (1976).
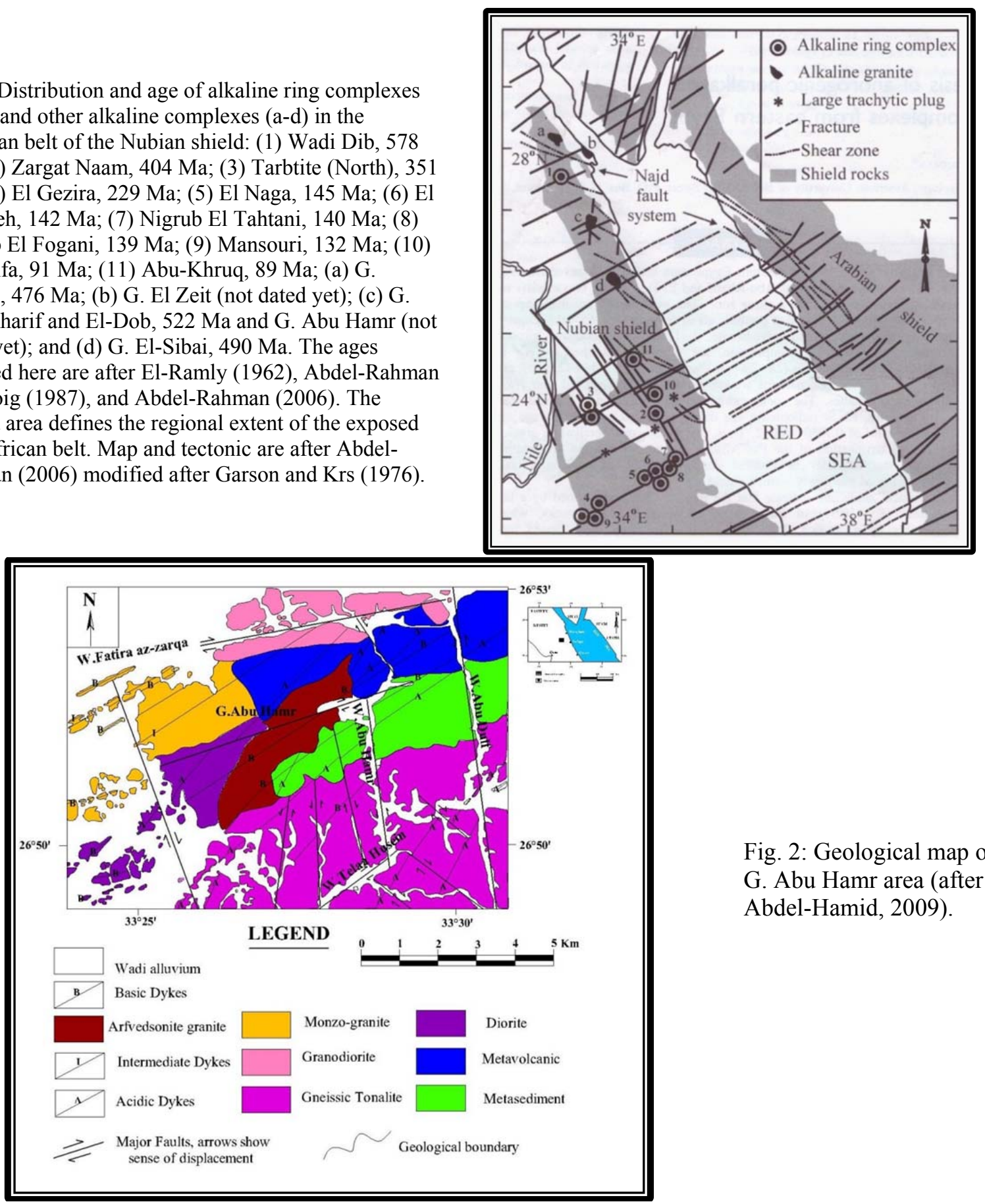

Fig. 2: Geological map of G. Abu Hamr area (after Abdel-Hamid, 2009).

\section{GEOLOGICAL SETTING}

G. Abu Hamr arfvedsonite granite pluton (Lat. 26 $51^{\prime} 30^{\prime \prime} \mathrm{N}$, Long. $33^{\circ} 27^{\prime} \mathrm{E}$ ), rising to a maximum elevation of $1780 \mathrm{~m}$, is represented by an elongated granitic mass trending in a NE-SW to ENE-WSW direction (Qena-Safaga shear zone trend), intrudes the Pan-African monzo-granites, granodiorites, gneissic tonalite, diorite, metavolcanics and metasediments country rocks (Figs. 1 and 2). It is slightly massive, highly fractured, well jointed and medium to coarse-grained ranging in color from white, pinkish-white to red. 


\section{Gabal Abu Hamr pluton: an example of A-type anorogenic peralkaline granites}

This pluton is divided by a major right lateral strike-slip fault trending ENE-WSW, along which hydrothermal solutions were emplaced causing the metasomatism of the granite. A shear zone having the same trend as the major fault is found near the contact between the granite and the metasediments. This zone, about $50 \mathrm{~m}$ long and $2 \mathrm{~m}$ thick along the southern part of the pluton, is characterized by strong episyenitization and hematitization (Fig. 3).

Quartz, aplite, jasperoid and black silica veins as well as basic dyke cross-cut the granitic pluton (Fig. 4). These granites are free of acidic dykes which invade the surrounding country rocks and are abruptly stopped at their peripheries.

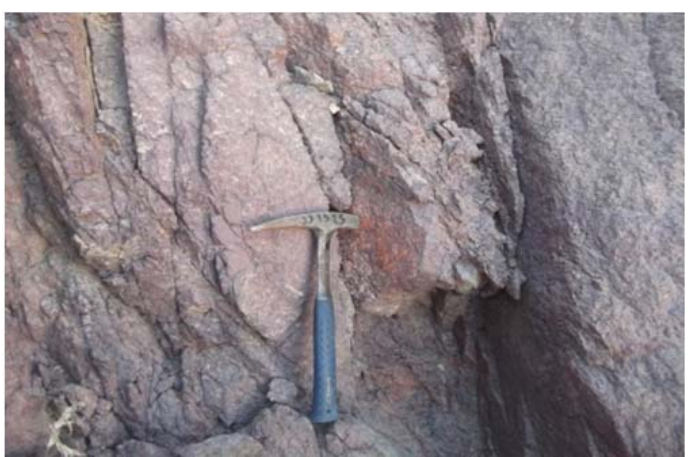

Fig. 3: Hematitization along the episyenitized shear zone in the arfvedsonite granite, W. Abu Hamr, Photo looking NE.

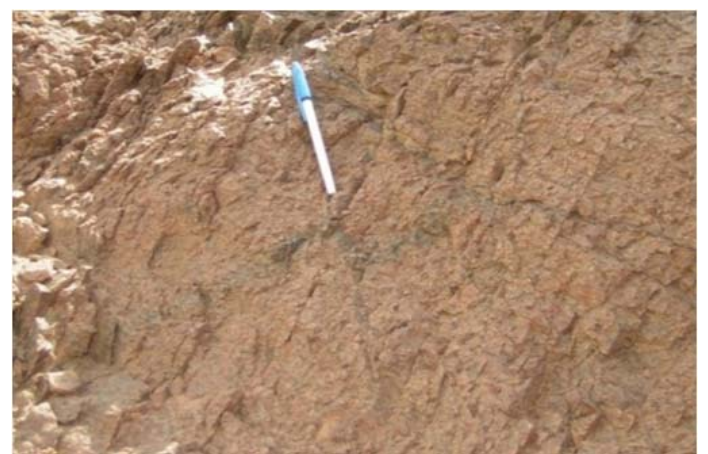

Fig. 4: Black silica veins displaced by dextral fault in the arfvedsonite granite, W. Abu Hamr, Photo looking NE.

\section{Petrography}

G. Abu Hamr pluton is composed of arfvedsonite granite. This granite is hypersolvus, equigranular and composed mainly of alkali feldspar (orthoclase perthite) with interstitial quartz, arfvedsonite and aegirine. Sphene, apatite, rutile, allanite, ilmenite and zircon are the common accessory minerals.

The alkali feldspars were the earliest essential minerals to crystallize. They are represented by perthite and anti-perthite which form up to $65 \%$ of the rock. Thin marginal rims of secondary albite occur between the perthite crystals. A strong sericitization which may reach the formation of secondary muscovite occurs along the anti-perthite lamellae.

Quartz occurs as primary or secondary anhedral crystals enclosed between the perthite crystals and exhibits wavy extinction.

Arfvedsonite occurs as large plates up to $5 \mathrm{~mm}$ long or as small acicular crystals interstitial between the alkali feldspar. The arfvedsonite plates are locally altered to riebeckite and astrophyllite, and mantled with aegerine crystals indicating the later crystallization in late magmatic stage (Fig. 5a).

Zircon, apatite and allanite are present as euhedral crystals and minute aggregation enclosed in the different essential minerals (Fig. 5b). Zircons also occur in different zones and generations suggesting different stages of crystallization.

This granite contains remarkable amouts of sphene (titanite), rutile and ilmenite enclosed in the arfvedsonite crystals. Colorless sphene is characterized by its high relief and cracking, while rutile is distinguished by its brownish color, also its high relief (Fig.6a).

Along the major fault, in the study area trending ENE-WSW dividing Abu Hamr pluton, hydrothermal solutions were emplaced causing metasomatic processes affecting the arfvedsonite granite. These solutions tend to change its mineralogical composition along the fault zone and along the shear zone formed as result of this fault. Along the major fault the granite changed its color being more reddish, composed of perthite, quartz and arfvedsonite crystals which totally replaced by opaques. The amount of the accessories became much reduced compared to the fresh arfvedsonite granite. This is due to the strong effect of the hydrothermal fluids which attacked the granite and led to the alteration and break down of the arfvedsonite crystals being transformed to opaque iron oxides (Fig. 6b). The irregularity and turbidity of perthite is also 
an indication that it suffered metasomatic processes (Fig. 6c). Putnis et al. (2007) suggest that this turbidity is not due solid state exsolutions but to subsolidus fluid rock interaction in which hematite precipitate in the pours of the alkali feldspars. The hydrothermal solutions caused a desilicification along the shear zone parallel to the major fault transforming the granite to episyenite which is composed of altered perthite, hematitized arfvedsonite and the dissolved quartz crystals being replaced by calcite, which crystallized in the cavities left after the dissolution of quartz (Fig. 6d).
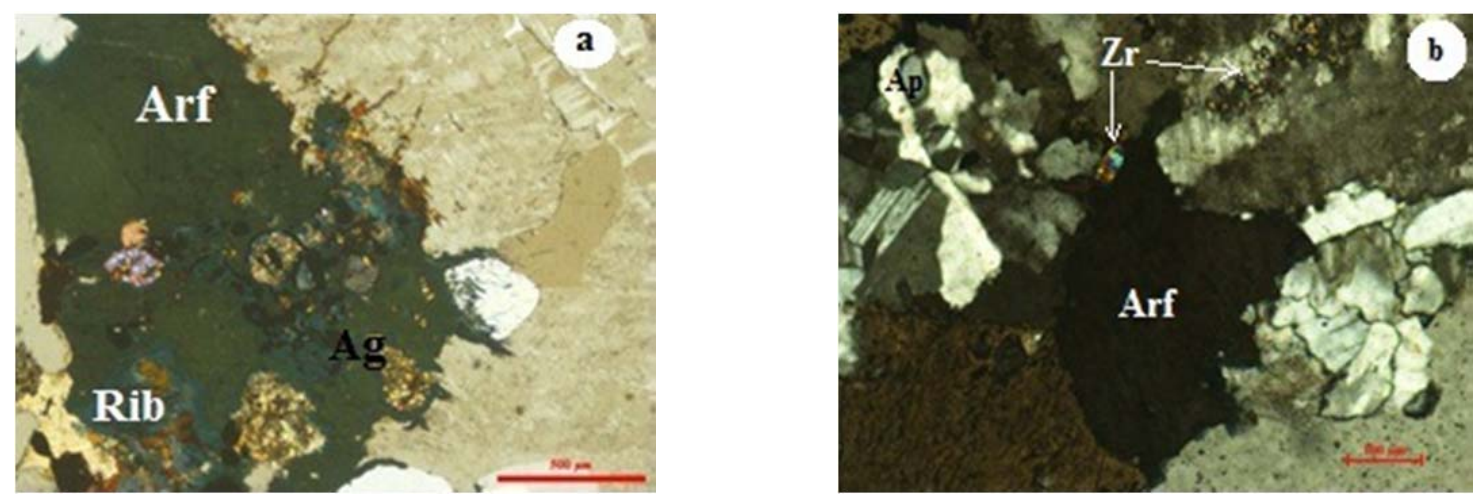

Fig. 5: a) Photomicrograph showing the alteration of the greenish arfvedsonite crystal (Arf) into the bluish riebeckite ( $\mathrm{Rib})$ with late aegirine crystal $(\mathrm{Ag})$ in the arfvedsonite granite, P.L. b) Photomicrograph showing euhedral zircon crystal (Zr) interstitial between arfvedsonite (Arf) and quartz crystals, minute aggregation of zircon crystals enclosed in alkali feldspar, Euhedral apatite crystal (Ap) also enclosed in quartz inthe arfvedsonite granite, C.N.

These mineralogical alterations indicate the alkaline nature of the hydrothermal solutions which attacked this granite after its emplacement. At the first stages, along the major fault hematitization, sericitization and break down of arfvedsonite crystals resulted in leaching of the enclosed accessory minerals and their transfer through the fractures to the brecciated contact with the metavolcanics contributing to the formation of uranium and molybdenum mineralizations.
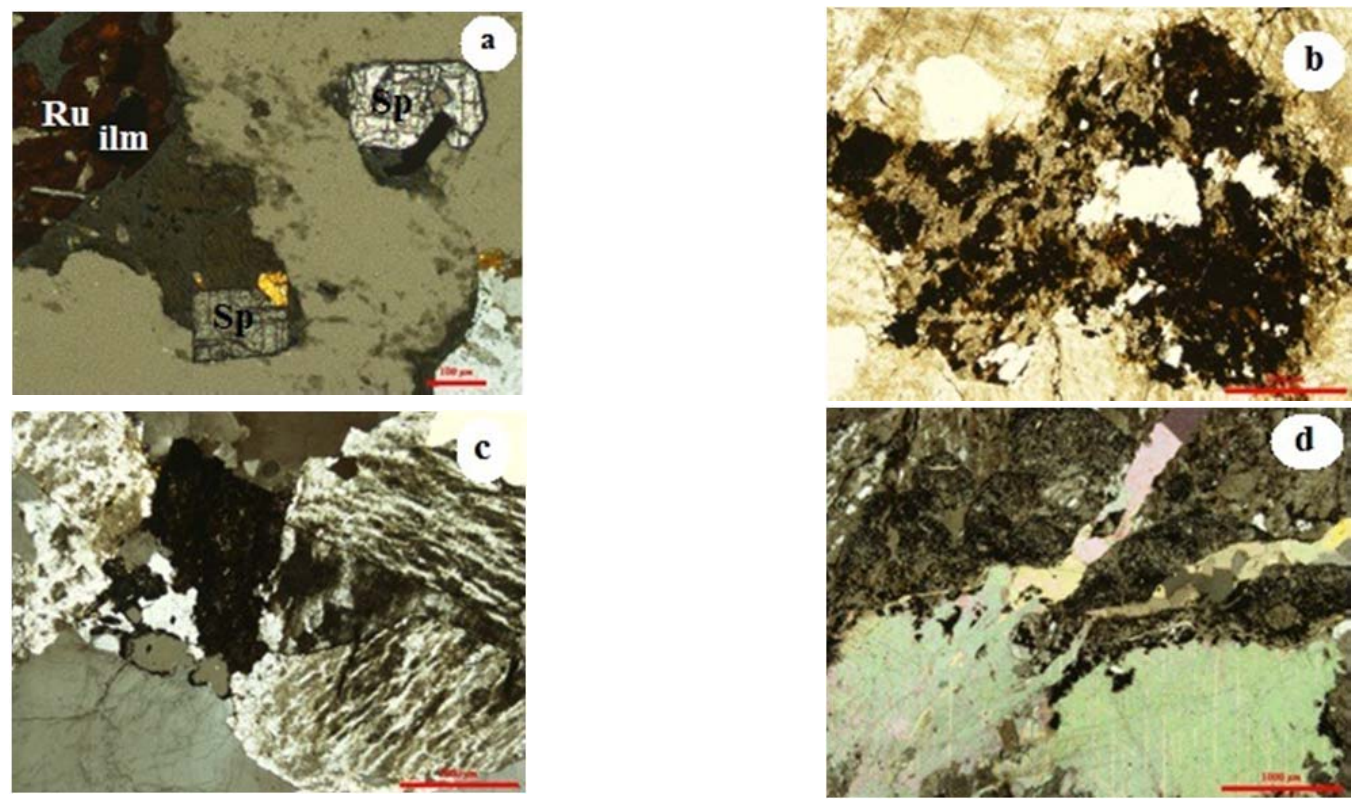

Fig. 6: a) Photomicrograph showing cracked sphene (Sp), brownish rutile $(\mathrm{Ru})$ and ilmenite (ilm) crystals enclosed in large arfvedsonite crystal (Arf) in the arfvedsonite granite, C.N. b) Photomicrograph showing the breakdown of arfvedsonite crystal and its transformation to iron oxides and opaques, P.L. c) Photomicrograph showing the irregularity and turbidity of perthite as indication of metasomtism of the arfvedsonite granite, C.N. d) Photomicrograph showing calcite veins and large calcite crystals in the episyenitized arfvedsonite granite, C.N. 
Gabal Abu Hamr pluton: an example of A-type anorogenic peralkaline granites

\section{GEOCHEMISTRY}

Major oxides, trace elements and REE of selective rock samples from G. Abu Hamr pluton were determined using 4 acid digestion Ultra trace ICP-MS analysis (package: MA250) at Bureau Veritas Commodities Canada Ltd.

\section{Major, trace and REE elements classification}

G. Abu Hamr alkaline granite is characterized by their high $\mathrm{SiO}_{2}$ contents, with average $75.05 \%$. The rock is highly depleted in $\mathrm{Al}_{2} \mathrm{O}_{3}$ (av. $9.65 \%$ ), $\mathrm{MnO}$ (av. $0.07 \%$ ), $\mathrm{MgO}$ (av. $0.08 \%$ ) and $\mathrm{CaO}$ (av. $0.34 \%$ ). They are moderately enriched in $\mathrm{Na}_{2} \mathrm{O}$ (av. $4 \%$ ) and slightly more enriched in $\mathrm{K}_{2} \mathrm{O}$ (av. $4.7 \%$ ) and $\mathrm{FeO}_{\mathrm{T}}$ (av. 5.2 \%) (Table 1).Regarding their trace elements, they are enriched in $\mathrm{Ba}$ (av. $367.7 \mathrm{ppm}$ ), Y (av. 56.72 ppm) and Ga (av. 26.03 ppm), while they exhibit abnormal depletion in Zr contents (av. 91.2 ppm) (Table 1). Their CIPW norm calculation shows that they consist mainly from normative quartz (av. 47.03), orthoclase (av. 28.06) and acmite (av. 7.88) with characteristic absence for both normative albite and anorthite (Table 1).

The absence of normative albite is due to the strong depletion in Al content, which leads to its consumption in the formation of K-Feldspar (orthoclase) with no Al left to form albite. As a result, the remaining $\mathrm{Na}$ content is taken in the Acmite formation. The absence of normative anorthite is due to the deficiency in $\mathrm{CaO}$ in these granites.

The REE elements abundance with normalized ratios and parameters (Anders and Grevesse, 1989) of G. Abu Hamr granites are presented in Table 1. Moreover, the Eu anomaly is estimated as $\mathrm{Eu} / \mathrm{Eu}^{*}$, where $\mathrm{Eu}^{*}=\left(\mathrm{Sm}_{\mathrm{n}}+\mathrm{Gd}_{\mathrm{n}}\right) / 2$.

The $\sum$ REE contents varies from 331 to $570 \mathrm{ppm}$, and is thus relatively higher than the average REE content of worldwide granite $(250 \mathrm{ppm})$ given by Herrmann (1970), with a relative enrichment in $\sum$ LREE $(288-530 \mathrm{ppm})$. Their relatively high LREE can be related to LREE-rich phases. The $\sum$ HREE varies between 37 and $46.1 \mathrm{ppm}$ being lower than the strongly enriched HREE characteristic of granites metasomatised by hydrothermal phenomena.

The $(\mathrm{La} / \mathrm{Yb})_{n}$ ratio (LREE/HREE ratio) of the studied granites varies from 6.82 to $14.88 \mathrm{ppm}$ (with average of 11.2) indicating a high degree of fractionation because the HREE (smaller cations) prefer entry into the early formed crystals leaving the residual melts progressively enriched in LREE (large cations). Also it is known that the $\mathrm{La} / \mathrm{Yb}$ ranges between (30 and 80 ) for metaluminous granites and between ( 1 and 9) for peralkaline granites (Harris and Marriner, 1980). This ratio in the arfvedsonite granites shows that they are more related to the alkaline type.

On the other hand, the fractionation of the LREE varies in a relatively wide range where $(\mathrm{La} / \mathrm{Sm})_{\mathrm{n}}$ ratio varies from 2.62 to $5.81 \mathrm{ppm}$. The $(\mathrm{Gd} / \mathrm{Yb})_{\mathrm{n}}$ ratio varies from 1.49 to 1.96 indicating the moderate fractionation of HREE (Table 1).

The Chondrite-normalized REE pattern (Sun and McDonough, 1989) of the considered granites is shown in Fig. (7). This pattern is characterized by a steep negative slope from $\mathrm{Ce}$ to $\mathrm{Eu}$, a partially or nearly flat HREE signature, a low to moderate negative Eu anomaly (0.025-0.042). These are characteristic features of pristine, alkaline A-type granites over the world (e.g. Abdel-Rahman and El-Kibbi, 2001; Vander Auwera et al., 2003 and Abdel-Rahman, 2006).

The Y/Ho ratio was proposed as a tool to identify non-charge and non-ionic size controlled magmatic trace element behavior such as that found in aqueous systems (Bau, 1996). The chondritic ratio of $\mathrm{Y} / \mathrm{Ho}$ is 28 (Andres and Grevesse, 1989) and any disturbance in this ratio is related to complexing agents (fluorine, chlorine, carbonate...etc). However, Bau (1996) suggest complexion with fluorine as the major cause for $\mathrm{Y} / \mathrm{Ho}$ values $>28$, while the complexion with bicarbonate is assumed to generate $\mathrm{Y} / \mathrm{Ho}$ values $<28$. In the studied granites, the average $\mathrm{Y} / \mathrm{Ho}$ is 24 . Being close to 28 , this may reflect the presence of complexes with bicarbonates and fluorine, or even the mobilization of $\mathrm{Y}$ as a result of alteration processes. 
Abdel-Hamid, et al.

Fig.7: Chondrite-normalized REEs pattern for arfvedsonite granites (Sun and McDonough, 1989).

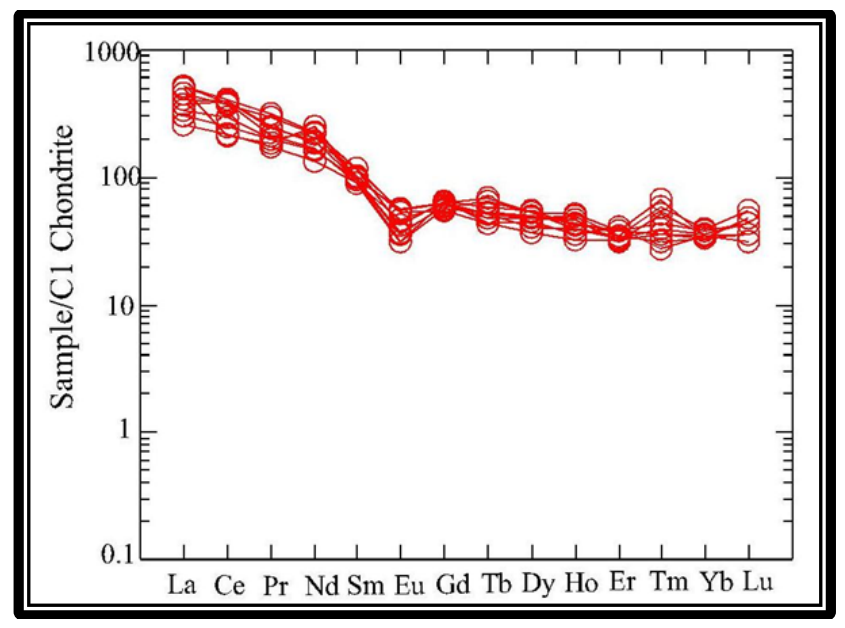

Table 1: Analysis of major elements (oxides wt \%), trace elements (ppm) and rare earth elements (ppm) for G. Abu Hamr arfvedsonite granite.

\begin{tabular}{|c|c|c|c|c|c|c|c|c|c|c|c|}
\hline $\begin{array}{l}\text { Rock } \\
\text { type }\end{array}$ & \multicolumn{11}{|c|}{ Arfvedsonite granites } \\
\hline Sample & $\mathrm{H} 7$ & H8 & H9 & $\mathrm{H} 10$ & H11 & H12 & H13 & H14 & H15 & H16 & Av. \\
\hline \multicolumn{12}{|l|}{$\begin{array}{l}\text { Plots } \\
\text { symbol }\end{array}$} \\
\hline $\mathrm{SiO} 2$ & 74.5 & 74.24 & 74.38 & 75.95 & 74.76 & 74.64 & 76.05 & 74.45 & 75.75 & 75.76 & 75.05 \\
\hline $\mathrm{TiO} 2$ & 0.15 & 0.3 & 0.3 & 0.2 & 0.12 & 0.25 & 0.09 & 0.21 & 0.2 & 0.08 & 0.19 \\
\hline $\mathrm{Al}_{2} \mathrm{O}_{3}$ & 9.75 & 9.7 & 9.84 & 9.64 & 9.95 & 9.85 & 9.25 & 9.67 & 9.54 & 9.37 & 9.65 \\
\hline $\mathrm{Fe}_{2} \mathrm{O}_{3}$ & 2.46 & 2.97 & 3.05 & 2.72 & 2.66 & 2.78 & 2.46 & 2.88 & 2.70 & 2.42 & 2.71 \\
\hline $\mathrm{FeO}$ & 2.21 & 2.67 & 2.74 & 2.44 & 2.33 & 2.72 & 2.18 & 2.84 & 2.64 & 2.33 & 2.51 \\
\hline $\mathrm{MnO}$ & 0.06 & 0.09 & 0.09 & 0.04 & 0.08 & 0.07 & 0.04 & 0.06 & 0.08 & 0.09 & 0.07 \\
\hline $\mathrm{MgO}$ & 0.09 & 0.11 & 0.09 & 0.05 & 0.06 & 0.04 & 0.09 & 0.13 & 0.05 & 0.06 & 0.08 \\
\hline $\mathrm{CaO}$ & 0.22 & 0.50 & 0.49 & 0.29 & 0.33 & 0.45 & 0.26 & 0.19 & 0.27 & 0.33 & 0.34 \\
\hline $\mathrm{Na} 2 \mathrm{O}$ & 3.87 & 4.2 & 4.05 & 3.77 & 3.96 & 4.15 & 4.02 & 4.04 & 3.75 & 4.13 & 3.99 \\
\hline $\mathrm{K} 2 \mathrm{O}$ & 4.76 & 4.98 & 4.76 & 4.7 & 4.57 & 4.88 & 4.49 & 4.46 & 5.01 & 4.52 & 4.71 \\
\hline $\mathrm{P} 2 \mathrm{O} 5$ & 0.016 & 0.018 & 0.018 & 0.014 & 0.013 & 0.017 & 0.016 & 0.018 & 0.015 & 0.016 & 0.016 \\
\hline L.O.I. & 1.89 & 0.21 & 0.16 & 0.2 & 1.67 & 0.1 & 1.01 & 0.98 & 0.12 & 0.87 & 0.72 \\
\hline Total & 99.99 & 99.99 & 99.98 & 99.99 & 99.91 & 99.95 & 99.95 & 99.93 & 99.92 & 99.97 & 100 \\
\hline $\mathrm{Cr}$ & 72 & 54 & 65 & 78 & 74 & 52 & 68 & 80 & 66 & 77 & 68.6 \\
\hline $\mathrm{Co}$ & 1.2 & 1.3 & 1.1 & 1.2 & 1.05 & 1.3 & 1.4 & 1.35 & 1.08 & 1.35 & 1.23 \\
\hline $\mathrm{Ni}$ & 4.7 & 2.7 & 3.6 & 3.9 & 3.7 & 2.66 & 4.6 & 4.9 & 2.89 & 4.78 & 3.84 \\
\hline $\mathrm{Cu}$ & 8.55 & 6.71 & 8.42 & 7.06 & 7.55 & 6.69 & 7.42 & 8.06 & 8.62 & 7.86 & 7.69 \\
\hline $\mathrm{Zn}$ & 114.9 & 118.2 & 130.1 & 51.4 & 120.9 & 122.2 & 127.1 & 81.4 & 117.1 & 131.4 & 111.5 \\
\hline $\mathrm{Zr}$ & 93.0 & 82.9 & 83.3 & 105.4 & 97.2 & 92.7 & 93.3 & 95.4 & 96.3 & 99.4 & 91.2 \\
\hline $\mathrm{Rb}$ & 86.2 & 56.8 & 54.9 & 89.5 & 83.2 & 86.8 & 84.9 & 85.5 & 64.9 & 87.5 & 78.02 \\
\hline Mo & 19.48 & 58.26 & 25.42 & 16.05 & 19.18 & 28.26 & 17.42 & 46.05 & 27.42 & 38.05 & 29.56 \\
\hline $\mathrm{Y}$ & 60.9 & 45.9 & 52.3 & 63.9 & 50.9 & 55.9 & 62.3 & 53.9 & 59.3 & 61.9 & 56.72 \\
\hline $\mathrm{Ba}$ & 218 & 502 & 489 & 222 & 418 & 202 & 469 & 319 & 449 & 389 & 367.7 \\
\hline $\mathrm{Pb}$ & 15.16 & 16.82 & 20.4 & 15.38 & 15.11 & 18.82 & 20.33 & 19.38 & 20.53 & 21.38 & 18.33 \\
\hline $\mathrm{Sr}$ & 27 & 35 & 39 & 61 & 32 & 43 & 56 & 48 & 46 & 41 & 42.8 \\
\hline $\mathrm{Ga}$ & 27.32 & 26.08 & 25.67 & 25.38 & 26.32 & 26.58 & 25.42 & 25.98 & 25.72 & 25.78 & 26.03 \\
\hline $\mathrm{V}$ & 4 & 5 & 4 & 5 & 4 & 5 & 4 & 5 & 4 & 5 & 4.5 \\
\hline $\mathrm{Nb}$ & 39.28 & 37.94 & 37.92 & 56.63 & 38.28 & 37.64 & 37.82 & 36.63 & 47.82 & 46.63 & 41.66 \\
\hline $\mathrm{Ta}$ & 2.5 & 1.8 & 1.9 & 3.3 & 2.1 & 2.3 & 3.2 & 1.8 & 2.7 & 2.0 & 2.36 \\
\hline $\mathrm{Hf}$ & 3.78 & 3.45 & 3.42 & 4.32 & 3.48 & 4.45 & 3.49 & 4.49 & 4.34 & 4.42 & 3.96 \\
\hline $\mathrm{Ag}$ & 0.036 & 0.043 & 0.079 & 0.02 & 0.032 & 0.041 & 0.069 & 0.035 & 0.057 & 0.02 & 0.045 \\
\hline $\mathrm{U}$ & 11.3 & 14.5 & 11.7 & 9.3 & 12.4 & 13.2 & 11.5 & 13.8 & 10.4 & 11.6 & 11.97 \\
\hline Th & 9 & 8 & 9.3 & 11 & 8.3 & 9.5 & 7.8 & 9 & 7.3 & 8.7 & 8.8 \\
\hline \multicolumn{12}{|c|}{ CIPW norms } \\
\hline $\mathrm{Q}$ & 47.51 & 44.07 & 45.09 & 48.09 & 47.64 & 45.22 & 49.54 & 47.08 & 46.43 & 48.79 & 47.03 \\
\hline Or & 28.69 & 29.56 & 28.19 & 27.77 & 27.35 & 28.91 & 26.84 & 26.66 & 29.63 & 26.98 & 28.06 \\
\hline $\mathrm{Ab}$ & 0 & 0 & 0 & 0 & 0 & 0 & 0 & 0 & 0 & 0 & 0 \\
\hline An & 0 & 0 & 0 & 0 & 0 & 0 & 0 & 0 & 0 & 0 & 0 \\
\hline ac & 7.24 & 8.59 & 8.82 & 7.87 & 7.77 & 8.04 & 7.18 & 8.40 & 7.80 & 7.05 & 7.88 \\
\hline
\end{tabular}


Gabal Abu Hamr pluton: an example of A-type anorogenic peralkaline granites

Table 1:Continued......

\begin{tabular}{|c|c|c|c|c|c|c|c|c|c|c|}
\hline \multirow{2}{*}{$\begin{array}{l}\text { Rock type } \\
\text { Sample }\end{array}$} & \multicolumn{10}{|c|}{ Arfvedsonite granites } \\
\hline & H7 & H8 & H9 & H10 & H11 & $\mathrm{H} 12$ & H13 & H14 & H15 & H16 \\
\hline \multicolumn{11}{|c|}{ Rare Earth Elements (ppm) } \\
\hline $\mathrm{La}$ & 60.9 & 108.3 & 120.8 & 71.9 & 65.7 & 118.3 & 98.3 & 78.4 & 122.4 & 88.7 \\
\hline $\mathrm{Ce}$ & 133.0 & 228.5 & 250.1 & 151.3 & 213.2 & 128.5 & 240.5 & 181.3 & 233.1 & 243.5 \\
\hline $\operatorname{Pr}$ & 16.5 & 27.9 & 29.8 & 19.0 & 26.3 & 17.9 & 23.9 & 19.05 & 19.8 & 23.2 \\
\hline $\mathrm{Nd}$ & 61.9 & 101 & 107 & 74.8 & 91.8 & 117 & 88 & 105.8 & 78 & 90 \\
\hline $\mathrm{Sm}$ & 13.7 & 15.9 & 17.6 & 14.9 & 16.2 & 15.4 & 17.9 & 14.6 & 13.6 & 14.9 \\
\hline $\mathrm{Eu}$ & 1.8 & 3.1 & 3.2 & 1.8 & 2.8 & 2.1 & 2.45 & 3.3 & 2.7 & 2.15 \\
\hline Gd & 11.6 & 11.3 & 12.9 & 13.3 & 12.6 & 12.3 & 13.08 & 12.8 & 12.6 & 12.06 \\
\hline $\mathrm{Tb}$ & 2 & 1.6 & 1.9 & 2.2 & 2.8 & 1.8 & 1.6 & 2.6 & 1.9 & 2.45 \\
\hline Dy & 12.4 & 9.3 & 10.2 & 13.7 & 8.4 & 12.3 & 11.3 & 13.3 & 12.2 & 13.3 \\
\hline Ho & 2.5 & 1.8 & 2.2 & 2.4 & 2.6 & 2.8 & 2.0 & 2.2 & 2.6 & 2.9 \\
\hline Er & 6.3 & 5.3 & 5.5 & 6.3 & 6.5 & 5.8 & 6.7 & 5.7 & 5.1 & 6.2 \\
\hline $\mathrm{Tm}$ & 1.1 & 0.9 & 1.0 & 0.9 & 1.2 & 0.8 & 0.7 & 1.5 & 1.3 & 1.7 \\
\hline $\mathrm{Yb}$ & 6.4 & 5.9 & 6.0 & 5.6 & 6.2 & 5.7 & 5.9 & 6.6 & 6.0 & 5.9 \\
\hline $\mathrm{Lu}$ & 1.1 & 0.9 & 1.1 & 0.9 & 1.0 & 1.2 & 0.8 & 1.4 & 1.1 & 0.8 \\
\hline$\sum$ REE & 331.3 & 521.7 & 569.3 & 379.0 & 457.3 & 441.9 & 513.1 & 448.6 & 512.4 & 507.8 \\
\hline$\sum$ LREE & 287.9 & 484.7 & 528.5 & 333.7 & 416.0 & 399.2 & 471.1 & 402.5 & 469.6 & 462.5 \\
\hline$\sum$ HREE & 43.4 & 37.0 & 40.8 & 45.3 & 41.3 & 42.7 & 42.1 & 46.1 & 42.8 & 45.3 \\
\hline$\sum_{\mathrm{E}} \mathrm{LREE} / \mathrm{HRE}$ & 6.6 & 13.1 & 13.0 & 7.4 & 10.1 & 9.3 & 11.2 & 8.7 & 11.0 & 10.2 \\
\hline Y/Ho & 24.36 & 25.5 & 23.77 & 26.62 & 19.57 & 19.96 & 31.15 & 24.5 & 22.8 & 21.34 \\
\hline \multicolumn{11}{|c|}{ Normalized Ratios (Anders and Grevesse, 1989) } \\
\hline$(\mathrm{La} / \mathrm{Yb}) \mathrm{n}$ & 6.83 & 13.67 & 14.44 & 9.21 & 7.6 & 14.88 & 11.95 & 8.52 & 14.63 & 10.78 \\
\hline$(\mathrm{La} / \mathrm{Sm}) \mathrm{n}$ & 2.87 & 4.39 & 4.43 & 3.11 & 2.62 & 4.96 & 3.54 & 3.46 & 5.81 & 3.84 \\
\hline$(\mathrm{Gd} / \mathrm{Yb}) \mathrm{n}$ & 1.49 & 1.58 & 1.78 & 1.96 & 1.68 & 1.78 & 1.84 & 1.60 & 1.74 & 1.69 \\
\hline $\mathrm{Eu} / \mathrm{Eu}^{*}$ & 0.025 & 0.039 & 0.036 & 0.022 & 0.033 & 0.026 & 0.027 & 0.042 & 0.036 & 0.027 \\
\hline
\end{tabular}

\section{Magma type and Petrogenesis}

The nature of the parent magma from which the G. Abu Hamr granitic rocks have been formed could be predicted through a number of diagrams based on geochemical parameters.

On the alkalinity variation diagram of Wright (1969), the data points of the arfvedsonite granites plot in the per-alkaline field (Fig. 8).

Concerning the alumina-saturation, the Shand's index (1951) A/NK vs. A/CNK diagram is used to distinguish between the different magma types (Fig. 9). The samples plot in the peraluminous field. The deviation of the arfvedsonite granites to the peraluminous field in this diagram may be due to the sever depletion in the calcium content, which may reflect that this type of granite was affected by metasomatic processes.

Frost et al. (2001) used the aluminum saturation index (ASI), which is defined as the molecular ratio A1/ $(\mathrm{Ca}-1 \cdot 67 \mathrm{P}+\mathrm{Na}+\mathrm{K})$ to classify the granitoids. They concluded that if $\mathrm{ASI}<1$ and $\mathrm{Na}+\mathrm{K}>\mathrm{Al}$ the rock will be peralkaline. According to Table 2, the arfvdesonite granites have an $\mathrm{ASI}<1$ and $\mathrm{Na}+\mathrm{K}>\mathrm{Al}$, which conclude that they are peralkaline.

Table 2: Some calculated geochemical parameters for G. Abu Hamr arfvedsonite granite.

\begin{tabular}{||l|c|c|c|c|c|c|c||}
\hline \multirow{3}{*}{ Sample No. } & \multicolumn{2}{|c|}{ Alumina-saturation index (Frost et al., } & \multirow{2}{*}{$\mathrm{Rb} / \mathrm{Sr}$} & \multirow{2}{*}{$\mathrm{K} / \mathrm{Rb}$} & \multirow{2}{*}{$\mathrm{Zr} / \mathrm{Hf}$} & $\mathrm{Nb} / \mathrm{Ta}$ \\
\cline { 2 - 5 } & $\mathrm{ASI}$ & $\mathrm{Al}$ & $\mathrm{Na}+\mathrm{K}$ & & & & \\
\hline $\mathrm{H} 7$ & 0.74 & 5.16 & 6.82 & 3.2 & 458.24 & 24.60 & 15.71 \\
\hline $\mathrm{H}_{8}$ & 0.67 & 5.13 & 7.25 & 1.62 & 728.87 & 24.03 & 21.07 \\
\hline $\mathrm{H}_{9}$ & 0.71 & 5.21 & 6.96 & 1.4 & 719.49 & 24.35 & 19.95 \\
\hline $\mathrm{H}_{10}$ & 0.74 & 5.10 & 6.69 & 1.5 & 434.67 & 24.40 & 17.16 \\
\hline $\mathrm{H}_{11}$ & 0.75 & 5.27 & 6.73 & 2.6 & 455.53 & 27.93 & 18.23 \\
\hline $\mathrm{H}_{12}$ & 0.70 & 5.21 & 7.13 & 2.02 & 466.59 & 20.83 & 16.36 \\
\hline $\mathrm{H}_{13}$ & 0.71 & 4.90 & 6.71 & 1.52 & 439.34 & 26.73 & 11.82 \\
\hline $\mathrm{H}_{14}$ & 0.75 & 5.12 & 6.70 & 1.78 & 432.75 & 21.25 & 20.35 \\
\hline $\mathrm{H}_{15}$ & 0.71 & 5.05 & 6.94 & 1.41 & 640.98 & 22.18 & 17.71 \\
\hline $\mathrm{H}_{16}$ & 0.70 & 4.96 & 6.81 & 2.13 & 428.57 & 22.48 & 23.31 \\
\hline \hline
\end{tabular}


On the $\mathrm{SiO}_{2}$ versus both $(\mathrm{FeOt} / \mathrm{FeOt}+\mathrm{MgO})$ and $\left(\mathrm{Na}_{2} \mathrm{O}+\mathrm{K}_{2} \mathrm{O}-\mathrm{CaO}\right)$ discrimination diagrams of Frost et al. (2001) (Fig. 10), the studied samples of the arfvdesonite granites fall within the A-type alkalic ferroan field.

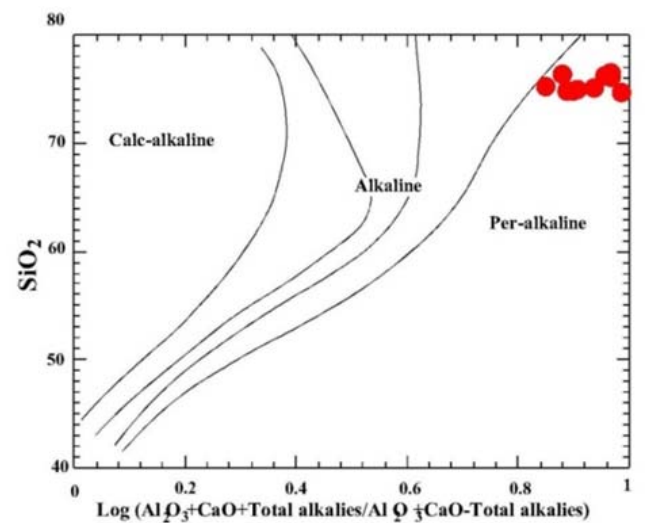

Fig. 8: Alkalinity ratio vs. $\mathrm{SiO}_{2}$ variation diagram for the arfvedsonite granite (Wright, 1969).

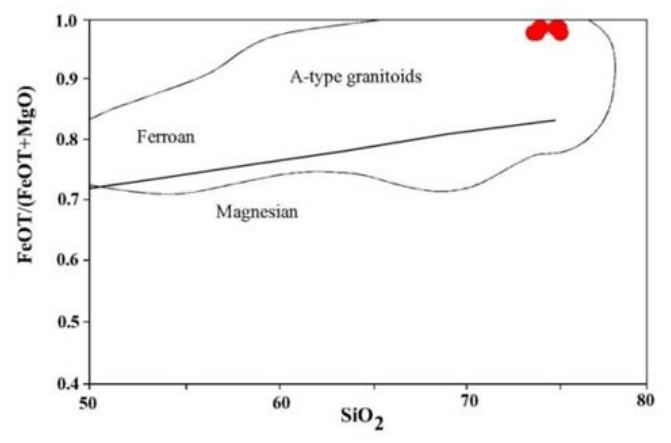

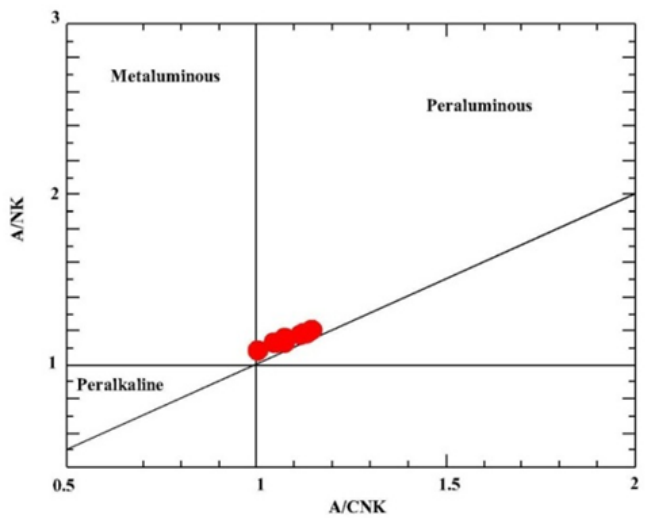

Fig. 9: Alumina-saturation Shand's index (1951).

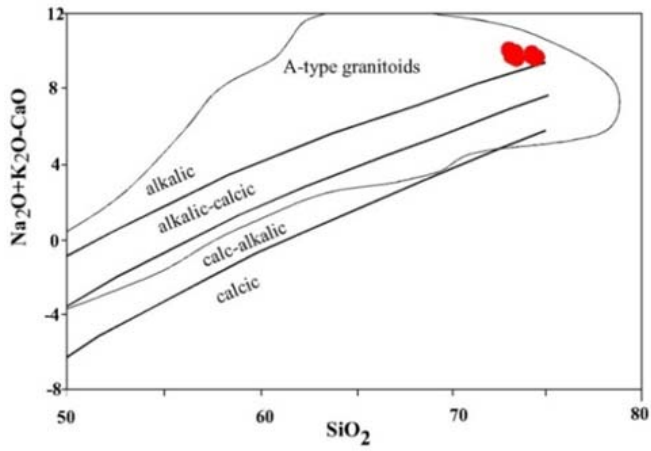

Fig10: $\mathrm{SiO}_{2}$ versus both $(\mathrm{FeOt} / \mathrm{FeOt}+\mathrm{MgO})$ and $\left(\mathrm{Na}_{2} \mathrm{O}+\mathrm{K}_{2} \mathrm{O}-\mathrm{CaO}\right)$ discrimination diagrams after Frost et al. (2001).

Using standard tectonic discrimination diagrams Maniar and Piccoli (1989) and Pearce et al. (1984), all data points plot in the field of the anorogenic rift-related granites (Fig. 11) and in the field of the A-type within-plate (Fig. 12).

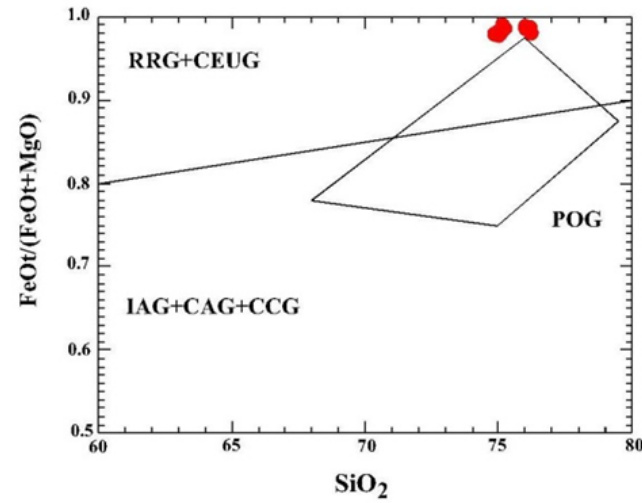

Fig.11: Manier and Picolli (1989) variation diagram for the arfvedsonite granite.

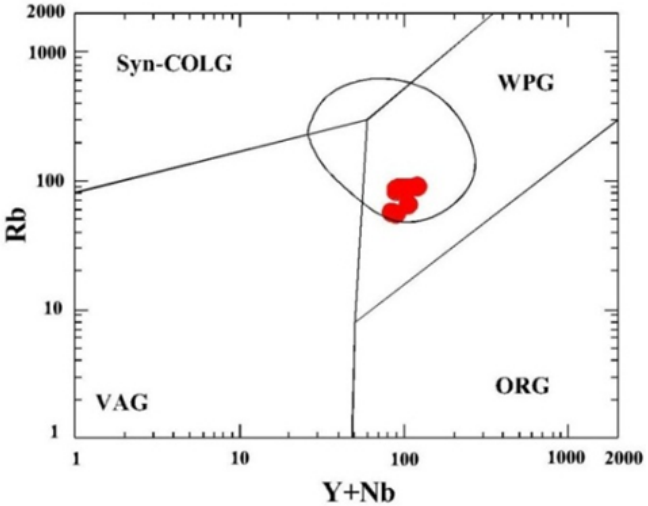

Fig.12: Pearce et al. (1984) variation diagram for the arfvedsonite granite, the circular field is the field of A-type granites (Whalen et al., 1987).

Eby (1992) differentiate the A-type granitoids into two subtypes. The first group $\left(\mathrm{A}_{1}\right)$ is related to sources generated by fractional crystallization like oceanic-island basalts (OIB) (truly anorogenic rifting). The second group $\left(\mathrm{A}_{2}\right)$ related to sources originally formed by partial melting of lower crust through 
Gabal Abu Hamr pluton: an example of A-type anorogenic peralkaline granites

subduction or continent-continent collision (post-orogenic setting). Using the $\mathrm{Y} / \mathrm{Nb}-\mathrm{Rb} / \mathrm{Nb}$ binary diagram of Eby (1992), the arfvedsonite samples plot clearly in the $A_{1}$ granite field of this diagram, which is a further evidence of their anorogenic setting (Fig. 13).

Granitic suites forming in association with compressional (orogenic) tectonic regimes such as Andean granites (Atherton et al., 1979) and the Pan-African calc-alkaline orogenic granites (Abdel-Rahman and Martin, 1987a) exhibit $\mathrm{Rb} / \mathrm{Sr}$ ratios $<1$, while those of anorogenic regimes exhibit $\mathrm{Rb} / \mathrm{Sr}$ ratios $>1$ such as in the case of the Amis anorogenic peralkaline granites of Namibia (Schmitt et al., 2000) which exhibit even higher $\mathrm{Rb} / \mathrm{Sr}$ ratios $(>30)$. Thus, the $\mathrm{Rb} / \mathrm{Sr}$ vs. $\mathrm{K} / \mathrm{Rb}$ diagram is found to be a useful discrimination between orogenic- and anorogenic granites. The plotted samples of the arfvedsonite granite fall in the anorogenic field (Fig. 14).

Moreover, the concentration of Ta ranges from 1.8 to $3.3 \mathrm{ppm}$, and the $\mathrm{Nb} / \mathrm{Ta}$ ratios range from 12 to 23 (Table 1), comparable to ratios characteristic of other anorgenic granitic complexes such as the G. Sabir anorogenic granites of Yemen $(7<\mathrm{Nb} / \mathrm{Ta}<20$; Capaldi et al., 1987), the G. El-Sibai A-type granite of Egypt $(13<\mathrm{Nb} / \mathrm{Ta}<20$; Abdel-Rahman and El-Kibbi, 2001), and the Amis Anorogenic peralkaline granites of Namibia $(12<\mathrm{Nb} / \mathrm{Ta}<23$; Schmitt et al., 2000). The concentration of Hf ranges from 3.42 to $4.49 \mathrm{ppm}$, and the average $\mathrm{Zr} / \mathrm{Hf}$ ratio is 23.9 (Table 2), a value that is almost the same as that of the Midian Mountain peralkaline granite of Saudi Arabia (Harris and Marriner, 1980).

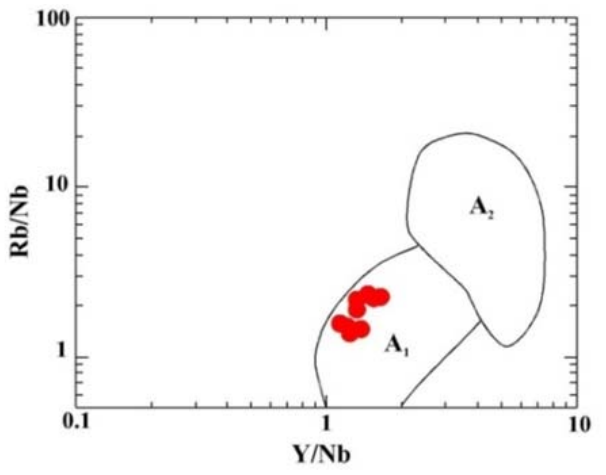

Fig.13: $\mathrm{Y} / \mathrm{Nb}-\mathrm{Rb} / \mathrm{Nb}$ binary diagram for the arfvedsonite granite (Eby, 1992).

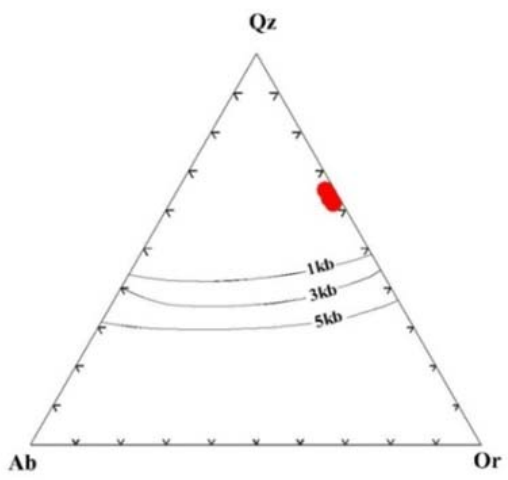

Fig.15: Normative Ab-Qz-Or ternary diagram for the arfvedsonite granite (Tuttle and Bowen, 1958).

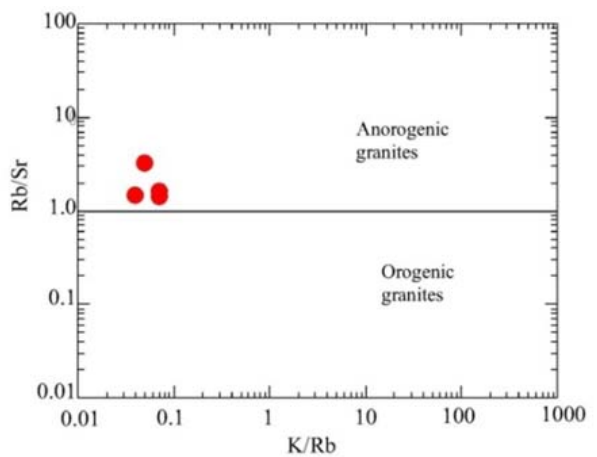

Fig. 14: $\mathrm{K} / \mathrm{Rb}$ vs. $\mathrm{Rb} / \mathrm{Sr}$ diagram for arfvedsonite granite, the line separating the fields of orogenic and anorogenic granites, after Abdel-Rahman and El-Kibbi (2001).

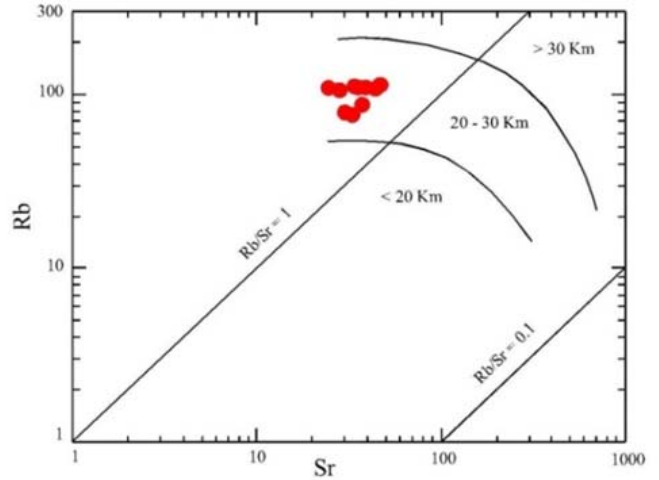

Fig.16: Rb-Sr discrimination diagram for the arfvedsonite granite (Condie, 1973).

The normative anorthite equal to zero in the arfvedsonite granites suggest a low pressure of crystallization. The position of data in the normative Qz-Ab-Or ternary diagram (Tuttle and Bowen, 1958), indicate that this type of granites crystallized at a water pressure below $1 \mathrm{~kb}$ (Fig.15).

The $\mathrm{Rb}$-Sr variation diagram (Condie, 1973), may explain the crustal thickness during the emplacement of the different granitic rocks. He distinguished different domains for thickness $<20 \mathrm{~km}, 20-30 \mathrm{~km}$ and $>30$ $\mathrm{km}$. The studied arfvedsonite granites have been intruded in a crust of thickness of 20-30 km (Fig.16). 


\section{Abdel-Hamid, et al.}

\section{DISCUSSION}

The presence of alkali amphibole (arfvedsonite), the hypersolvus nature of the feldspars and the general peralkaline character of G. Abu Hamr peralkaline granite indicate that they conform to the mineralogical and geochemical traits typical of within-plate A-type suites. However, some petrographical and chemical parameters clearly indicate that this granite has been affected by hydrothermal metasomatism (e.g.: Chemically, the abnormal depletion of zirconium and HREE's contents, the enrichment of $\mathrm{K}_{2} \mathrm{O}$ is not followed by similar enrichment in $\mathrm{Rb}$. Also, the depletion in the $\mathrm{Sr}$ not followed by $\mathrm{Rb}$ increase is also evidence of these processes. Petrographically, the desilicifications of the granite (episyenitization) along the southern shear zone and the crystallization of low temperature calcite crystals filling the cavities resulting from the dissolution of quartz while the dissolved quartz led to the formation of the quartz veins dissecting the granite).

Different models are proposed for the formation of A-type granites: 1) fractionation of mantle-derived magmas, 2) partial melting of various crustal sources with variable contamination from mantle-derived magmas, and 3) lower-crust metasomatism by alkali rich mantle-derived fluids leading to fertilization and melting of the crust (Schmitt el al., 2000; Frost et al., 2002 and Vander Auwera et al., 2003). A-type granitoids have been subdivided into two groups based on multi-trace element ratios:1) type $A_{1}$, related to sources similar to those of oceanic island basalt (OIB), and 2) type $A_{2}$, related to sources originally formed by subduction or continent-continent collision (Eby, 1990, 1992). G. Abu Hamr granite belongs to the $\mathrm{A}_{1^{-}}$ type directly derived from the mantle.

According to Bonin (1990), during the first 100 Ma following the end of a major orogeny (Pan-African orogeny in this case), a new mantle source replaces the old complex system of mixed oceanic-continental crust-mantle sources and produces alkaline melts which are subsequently less and less contaminated by crustal host rocks.

This magma ascent may have been facilitated along fissures and reactivation of pre-exciting PanAfrican fractures. In our case, this is the Najd strike-slip fault system. Accordingly, the emplacement of G. Abu Hamr pluton took place along the deep-seated fracture zone of the Precambrian E-NE lineaments which controlled the Red Sea rifting direction during this extensional tectonic regime (Fig. 1).

This pluton is believed to be the northern extension of G. Abu Kharif and El-Dob, located at the southern part of the mapped area, since the three plutons were emplaced along the same E-NE lineament.

Thus, we suggest that G. Abu Hamr pluton was originated from an alkaline magma which was derived directly from the upper mantle and any imprint of crustal contamination is due to the effect of the hydrothermal solutions percolating through the different levels of the crust.

Haridy (2002) studied the structural events affecting the north and central Eastern Desert and he defined a major Devonian-Pre-Jurassic compressional event trending NE-SW and ENE-WSW, resulting from the collision of Gondwana-Laurissia which started at late Devonian (Kohn et al., 1992 and Bojar et al., 2002).

This event produced a right strike-slip fault dividing G. Abu Hamr pluton in the middle (Fig. 2). This major fault provided the perfect pathways for the rising of hydrothermal solutions and their percolation along it causing alkali metasomatism (mainly potassic) of the granite.

Alkaline magmas are strongly enriched in incompatible elements, such as Ti, $\mathrm{P}, \mathrm{Y}, \mathrm{Zr}, \mathrm{Nb}, \mathrm{Ba}, \mathrm{K}, \mathrm{Na}$, $\mathrm{Rb}, \mathrm{Sr}, \mathrm{Th}, \mathrm{U}, \mathrm{F}$, and REE. Also the alkalinity of the magma favors the stabilization of alkali zirconosilicate complexes in the melt and prevents its saturation in zircon (Watson, 1979). The crystallization of alkali amphibole is expected to remove fluorine and alkalis from the melt, destabilizing the zirconosilicate complexes (which may be fluorinated: Collins et al. 1982), and resulting in eventual precipitation of metamict zircon recorded in the arfvedsonite granite.

Temperature-pressure conditions for $\mathrm{K}$ metasomatism are not well known, but a minimum temperature of $630^{\circ} \mathrm{C}$ in the Q-Ab-Or system at $1 \mathrm{kbar}$, with $4 \% \mathrm{~F}$, is considered possible (Manning, 1982; Pollard, 1983). Studies of fluid inclusions in $\mathrm{K}$-feldspars indicate a range of temperatures from $320^{\circ} \mathrm{C}$ to $700^{\circ} \mathrm{C}$, at 1.2 to 2 kbar (Pirajno, 2013). 


\section{Gabal Abu Hamr pluton: an example of A-type anorogenic peralkaline granites}

These alkaline solutions caused the continuation of stability of the alkali zirconosilicate complexes, HREE complexes and uranyl complexes and their solubility in the fluids. According to Mineyev (1963), some REE complexes such as $\mathrm{NaYF}_{4}$ and $\mathrm{Na}_{5} \mathrm{Ce}_{3} \mathrm{~F}_{14}$ have been experimentally demonstrated to be stable under hydrothermal and supercritical conditions. Morever, Kosterin (1959) and Langmuir (1978) have demonstrated that carbonate complexes of the HREE and uranyl ions are stable under relatively alkaline and oxidizing conditions. This would allow for the transport of the HREE and $U$ and their concentration in late stage fluids such as those responsible of the metasomatism of the arfvedsonite granite. These fluids keep moving through the fractures till the contact between the granite and metavolcanics, where the conditions changed leading to the destabilization of the soluble complexes and formation of zircon crystals, uranium and molybdenum mineralizations.

The dissolution of quartz and cooling change the solutions into more acidic and the low temperature calcite filled the cavities on the southern shear zone. Also, at this stage the intensive reaction of the low temperature $\left(120-200^{\circ} \mathrm{C}\right)$ aqueous soultions on the metamict zircon crystals of the granite cause their loss of $\mathrm{Zr}$, Si as well as radiogenic $\mathrm{Pb}$ (Geisler et al., 2003). All these processes lead to concentration of zirconium in the residual fluids and its escape from the granite leading to the abnormal depletion of the later.

The presence of enrichment of zircon crystals at the contact between the granite and metavolcanics (El Manawi et al., 2009) as well as their abundance in the outer impure talc zone which occur at the contact between the metavolcanics and the granodiorite (Bishay and Ayoub, 2010) confirms the escape of $\mathrm{Zr}$ into the fluid and its transportation through the fractures and structure systems in the area.

Since the emplacement of G. Abu Hamr peralkaline granite took place after the termination of the PanAfrican orogeny cycle $(\sim 550 \mathrm{Ma})$ and it was affected by the late Devonian event, we suggest an estimated age for G. Abu Hamr arfvedsonite granite ranging from 550 Ma to about 450 Ma. Further age dating analysis is needed to determine its exact age.

\section{CONCLUSIONS}

1- G. Abu Hamr pluton is an elongated granitic mass intruded into voluminous Pan-African country rocks along the E-NE shear zone in the Eastern Desert of Egypt known as Qena-Safaga shear zone. This pluton may be considered as the northern extension of G. Abu Kharif and El-Dob emplaced along the same shear trend.

2- Mineralogically, the rock is composed mainly of perthite, quartz, arfvedsonite and late aegerine with accessory sphene, rutile, allanite, ilmenite and zircon.

3- Its mineralogical and geochemical traits are typical of the within-plate A-type suites. However, some petrographical and chemical parameters clearly indicate that this granite has been affected by hydrothermal metasomatism (e.g. depletion of $\mathrm{Zr}$ ).

4- Along the late Devonian ENE-WSW major fault, dividing G. Abu Hamr, hydrothermal solutions caused the metasomatism of G. Abu Hamr arfvedsonite granite and lead to the escape of $\mathrm{Zr}$ and its transportation by fluids rich in $\mathrm{Zr}, \mathrm{U}$, HREE through the structure systems and concentrated along the tectonic contact between the granite and the metavolcanics leading to the formation of $\mathrm{U}$ and $\mathrm{Mo}$ mineralizations.

5- The estimated age of the emplacement of this pluton is suggested to range from $550 \mathrm{Ma}$ to $450 \mathrm{Ma}$.

6- G. Abu Hamr arfvedsonite granite can be considered as one of the A-type anorogenic peralkaline plutons present in the Eastern Desert of Egypt.

\section{REFERENCES}

Abdel-Hamid, H. M. (2009): Geological and geochemical factors affecting the distribution of radioelements in Gabal Abu Hamr area, North Eastern Desert, Egypt, M. Sc. Thesis, Cairo University, Egypt, 196p.

Abdel-Rahman, A. M. (1995): Tectonic-magmatic stages of shield evolution, the Pan-African belt in Northeastern Egypt. Tectonophysics, 242, 223-240.

Abdel-Rahman, A. M. (2006): Petrogenesis of anorogenic peralkaline granitic complexes from eastern Egypt. Mineral. Mag., 70(1), 27-50. 
Abdel-Rahman, A. M. and Doig, R. (1987): The Rb-Sr geochronological evolution of the Ras Garib segment of the Northern Nubian Shield. J. Geol. Soc. London, 144, 577-586.

Abdel-Rahman, A. M. and El-Kibbi, M. M. (2001): Anorogenic magmatism: chemical evolution of the Mount El-Sibai A-type complex (Egypt), and implications for the origin of within-plate felsic magmas. Geol. Mag., 138(1), 67-85.

Abdel-Rahman, A. M and Martin, R. F. (1987): Late Pan-African magmatism and crustal development in northerastern Egypt. Geol. J., 22, 281-301.

Abdel-Rahman, A. M. and Martin, R. F. (1990): The Mount Gharib A-type granite, Nubian shield: petrogenesis and role of metasomatism at the source. Contrib. Mineral. Petrol., 104, 173-183.

Anders, E. and Grevesse, N. (1989): Abundances of the elements: Meteoritic and solar. Geochim. et Cosmochim. Acta, 53: 197-214.

Atherton, M. P., McCourt, W. J, Sanderson, L. M. and Taylor, W. P. (1979): The geochemical character of the segmented Peruvian Coastal batholith and associated volcanics. p. 45-64 in: Origin of Granire Batholiths: Geochemical Evidence (M.P. Atherton and J. Tarney, editors). Shiva, Cheshire, UK.

Bau, M. (1996): Controls on the fractionation of isovalent trace elements in magmatic and aqueous systems: evidence from $\mathrm{Y} / \mathrm{Ho}, \mathrm{Zr} / \mathrm{Hf}$, and lanthanide tetrad effect. Contrib. Mineral. Petrol., 123: 323333.

Beyth, M., Stern, R. J., Altheer, R., Kröner, A. (1994): The late Precambrian Timena igneous complex, southern Israel: evidence for comagmatic-type sanukitoid monzodiorite and alkali granite magma. Lithos: 31, 103-124.

Bishay, A. F. and Ayoub, R. R. (2010): The significance of radioactivity in relation to zircon and accessory minerals in the talc rocks at Gabal Abu Hamr area, north Eastern Desert, Egypt. $5^{\text {th }}$ Inter. Conf. geol. Tethys Realm, South Valley Univ., 361-371.

Bonin, B. (1990): From orogenic to anorogenic settings: evolution of granitoid suites after a major orogenesis, Geol. J., 25, 261-270.

Bojar, A.-V., Fritz, H., Kargl, S. and Unzog, W. (2002): Phanerozoic tectonothermal history of the Arabian- Nubian shield in the Eastern Desert of Egypt: evidence from fission track and paleostress data. J. Afr. Earth Sci., 34, 191-202.

Capaldi, G., Chiesa, S., Magnetti, P., Orsi, G. and Poli, G. (1987): Tertiary anorogenic granites of the western border of the Yemen plateau, Lithos, 20, 433-444.

Condie, K. C. (1973): Archean magmatism and crustal thickening. Geol. Soc. Am. Bull., 84, 2981-2992.

Collins, W. J., Beams, S. D., White, A. J. R. and Chappell, B. W. (1982): Nature and origin of A-type granites with particular reference to southeastern Australia. Contrib Mineral Petrol 80, 189-200.

Eby, N. G. (1990): The A-type granitoids; a review of their occurrence and chemical characteristics and speculations on their petrogenesis. Lithos, 26, 115-134.

Eby, G. N. (1992): Chemical subdivision of the A-type granitoids: petrogenetic and tectonic implications. Geology 20, 641-644.

El Manawi, A. W., Abdel Warith, A. and Abdel-Hamid, H. M. (2009): Uranium mineralization along the contact between peralkaline granites and metavolcanics of Gabal Abu Hamr, north Eastern Desert, Egypt, Delta J. Sci. (Geo.) 33, 313 -325.

El-Ramly, M. F. (1962): The absolute ages of some basement rocks in the Eastern and South-Western Desert of Egypt. Geological Survey of Egypt, Paper 15, 12pp.

Farahat, E. S., Shaaban, M. M., Abdel Aal, A. Y. (2007): Mafic xenoliths from Egyptian Tertiary basalts and their petrogentic implications. Gondwana Res.: 11, 516-528.

Farahat, E. S., Zaki, R., Hauzenberger, C., Sami, M. (2011): Neoproterozoic calc-alkaline peraluminous granitoids of the Deleihimmi pluton, Central Eastern Desert, Egypt: implications for transition from late- to post- collisional tectonomagmatic evolution in the northern Arabian-Nubian Shield. Geol. J.: 46, 544-560.

Frisch, W. and Abdel-Rahman, A. M (1999): The Wadi Dib ring complex, eastern Egypt: A mantle derived A-type suite. Mineralogy and Petrology 65, 249-275.

Frost, B. R., Barnes, C. G., Collins, W. J., Arculus, R. J., Ellis, D. J. and Frost, C. D. (2001): A Geochemical Classification for Granitic Rocks. J. Petrol., 42, 2033-2048. 
Gabal Abu Hamr pluton: an example of A-type anorogenic peralkaline granites

Frost, C. D., Frost, B. R., Bell, J. M. and Chamberlain, K. R. (2002): The relationship between A-type granites and residual magmas from anorthosite: evidence from the northern Sherman batholith, Laramie Mountains, Wyoming, USA. Precamb. Res., 119, 45-71.

Garson, M. S. and Krs, M. (1976): Geophysical and geological evidence of the relationship of the Red Sea tranverse tectonics to ancient fractures. Geol. Soc. Am. Bull., 87, 169-181.

Geisler, T., Rashwan, A. A., Rahn, M. K. W., Poller, U., Zwingmann, H., Pidgeon, R. T., Schleicher, H. and Tomaschek, F. (2003): Low-temperature hydrothermal alteration of natural metamict zircons from the Eastern Desert, Egypt. Mineralogical Magazine 67, 485-508.

Haridy, H. M. (2002): Geotechnical and geotectonic studies on G. Gattar U-province and their implication on localization target structures for U-exploration. Ph. D. Thesis, Cairo Univ.330 p.

Harris, N.B.W. and Marriner, G.R. (1980): Geochemistry and Petrogenesis of a peralkaline granite complex from the Midian mountains, Saudi Arabia. Lithos, 13, 237-325.

Herrmann, A. G. (1970): Yttrium and lanthanides. In: K. H Wedepohl (ed.), Handbook of geochemistry, II/2, Springer-Verlage, Berline, 39-57.

Kinnaird, J.A. (1985): Hydrothermal alteration and mineralisation of the alkaline anorogenic ring complexes of Nigeria. J Afr Earth Sci 3, 229-252.

Kohn, B. P., Eyal, M. and Feinstein, S. (1992): A major Late Devonian-Early Carboniferous (Hercynian) thermotectonic event at the NW margin of the Arabian-Nubian shield: evidence from zircon fission track dating. Tectonics 11/5, 1018-1027.

Kosterin, A. V. (1959): The possible modes of transport of the rare earths by hydrothermal solutions. Geochemistry, 381- 387.

Landoll, J. D., Foland, K. A. and Henderson, C.M.B. (1994): Nd-isotopes demonstrate the role of contamination in the formation of coexisting quartz- and nepheline syenites at the Abu Kruq complex, Egypt. Contributions to Mineralogy and Petrology, 117, 305-329.

Langmuir, D. (1978): Uranium solution-mineral equilibria at low temperatures with applications to sedimentary ore deposits: Geochim. et Cosmochim., Acta 42, 547-569.

Maniar, P. D. and Piccoli, P. M. (1989): Tectonic discrimination of granitoids. Geol. Soc. Am. Bull., 101, 635-643.

Manning, D. C. (1982): An experimental study of the effects of fluorine on the crystallization of granite melts. In: Evans AM (ed) Metallization associated with acid magmatism. Wiley, Chichester, p. 191-203.

Mineyev, D. A. (1963): Geochemical Differentiation of the rare earths. Geokhimiya 12, 1082- 1100.

Pearce, J. A., Harris, N. B. W. and Tindle, A. G. (1984): Trace element discrimination diagrams for the tectonic interpretation of granitic rocks. J. Petrol., 25(4), 956-983.

Pirajno, F. (2013): Effects of Metasomatism on Mineral Systems and Their Host Rocks: Alkali Metasomatism,Skarns, Greisens, Tourmalinites, Rodingites, Black-Wall Alteration and Listvenites, Chapter7 in: Metasomatism and the Chemical Transformation of Rock, Lecture Notes in Earth System Sciences, (D.E. Harlov and H. Austrheim editors) at Springer-Verlag Berlin Heidelberg, p. 203-251.

Pollard, P. J. (1983): Magmatic and postmagmatic processes in the formation of rocks associated with rare element deposits. Trans Inst Min Metall 92:B1-B9.

Putnis. A., Hinrichs. R., Putnis. C. V., Golla-Schindler, U. and Collins, L. G. (2007): Hematite in porous redclouded feldspars: evidence of large-scale crustal fluid-rock interaction. Lithos 95, 10-18.

Schmitt, A. K., Emmermann, R., Trumbull, R. B., Bühn, B. and Henjes-Kunst, F. (2000): Petrogenesis and ${ }^{40} \mathrm{Ar} /{ }^{39} \mathrm{Ar}$ geochronology of the Brandberg complex, Namibia: Evidence for a major mantle contribution in metaluminous and peralkaline granites. Journal of Petrology, 41, p. 1207-1239.

Shand, S. J. (1951): Eruptive rocks, John Willey, New York. John Willey \& Sons, 488 p.

Stern, R. J. (2002): Crustal evolution in the East African Orogen: a Neodymium isotopic perspective. Journal of African Earth Sciences: 34, p.109-117.

Stern, R. J., Ali, K. A., Liegeous, J. P., Johnson, P. R., Kozdroj, W., Kattan, F. H. (2010): Distribution and significance of Pre-Neoproterozoic igneous rocks of the Arabian-Nubian Shield. American Journal of Science: 310, p.791-811.

Stoeser, D. B., Frost, C. D. (2006): Nd, Pb, Sr, and O isotopic characterization of Saudi Arabian Shield terranes. Chemical Geology: 226, p.163-188. 


\section{Abdel-Hamid, et al.}

Sun, S. S. and McDonough, W. F. (1989): Chemical and isotopic systematic of oceanic basalts: implications for mantle composition and processes. In: Saunders, A.D., Norry, M.J. (Eds.), Magmatism in the Ocean Basins. J. Geol. Soc., Spec. Publ. 42: 313- 345.

Tuttle, O. F. and Bowen, N. L. (1958): Origin of granite in the light of experimental studies in the system $\mathrm{NaAlSi}_{3} \mathrm{O}_{8}-\mathrm{KAlSi}_{3} \mathrm{O}_{8}-\mathrm{SiO}_{2}-\mathrm{H}_{2} \mathrm{O}$. Geol. Soc. Am. Mem., 74, 153p.

Vander Auwera, J., Bogaerts, M., Liégeois, J-P., Demaiffe, D., Wilmart, E., Bolle, O. and Duschesne, J.-C. (2003): Derivation of the 1.0-0.9 Ga ferro-potassic A-type granitoids of southern Norway by extreme differentiation from basic magmas. Precamb. Res., 124, p. 107-148.

Watson, E. B. (1979): Zircon saturation in felsic liquid: Experimental results and applications to trace elements geochemistry. Contrib. Mineral, Petrol. 70, 407-419.

Whalen, J. B., Currie, K. L. and Chappell, B.W. (1987): A-type granites: geochemical characteristics. Discrimination and petrogenesis Contrib. Mineral. Petrol. 87, 319-327.

Wright, J. B. (1969): A simple alkalinity ratio and its application to questions of non-orogenic granite genesis. Geol. Mag., 106 (4): 370-384. 
Gabal Abu Hamr pluton: an example of A-type anorogenic peralkaline granites

$$
\begin{aligned}
& \text { جبـل أبو همر جرانيت: مثال للصخور فوق القلوية اللا تصادمية الموجودة بمصر } \\
& \text { هثام محمود عبد الحميد²، زينب محمد عبد القادر 1، عبد الحميد وجدى المناوى1 وعبد العزيز عبد الوارث2 } \\
& \text { ا كلية العلوم جامعة القاهرة . ليئة المواد النووية. } \\
& \text { الخـلاصة }
\end{aligned}
$$

يقع جبل أبو همر في شمال الصحراء الثرقية لمصر كجزء من المنطقة الثمالية للارع العربى النوبي. يتكون جبل أبو همر من كتلة جرانيتية (أرفذزونيت جرانيت) تخترق صخور قاعديه ما قبل العصر الكمبري و ذلك على طول ما يسمى إنجاة منطقة

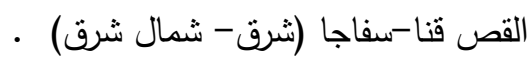
تتقسم تلك الكتلة الجرانيتية بواسطة صدع رئيسى بإتجاة شرق شمال شرق- غرب جنوب غرب مما ساعد على تصاعد

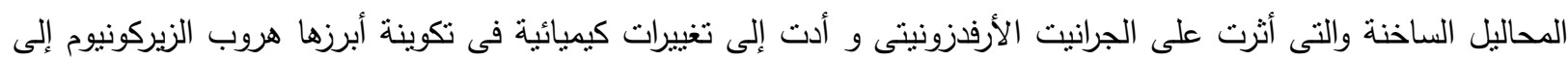

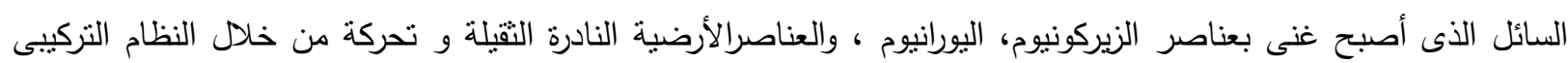
(إتجاة شمال شمال شرق- جنوب جنوب غرب) و تركيزها على خط التماس بين الجرانيت الأرفدزينتى و الصخور البركانية

يمكن إعتبار جبل أبو همر جرانيت الإمتداد الثمالى لكل من جبل أبو خريف و جبل الدب الواقعيين على نفس إتجاة منطقة القص جنوب المنطقة. يترواح العمر الإفتراضى لجبل أبو همر جرانيت ما بين .00 - .0 ـ مليون سنة. 